\title{
Penguatan Generasi Cerdas, Kreatif, dan Berkarakter bagi Siswa, Guru, dan Tendik MIM Janti Klaten
}

\author{
Ahmad Muhibbin ${ }^{1}$, Wibowo Heru Parsetiyo ${ }^{2}$, Ridwan Cahya Saputra ${ }^{3}$, Wiwin Novita Sari ${ }^{4}$, Yuliana \\ Indah Fatmawati ${ }^{5}$, Risang Galih Pramudika ${ }^{5}$, Annisa Laylatun Nashiroh ${ }^{6}$, Hariyanti ${ }^{7}$, Nonik Wulan \\ Sawitri $^{8}$, Aulia Indah Saputri ${ }^{9}$, Farizki Yunarta ${ }^{10}$, Husna Imro'atush Sholihah ${ }^{11}$

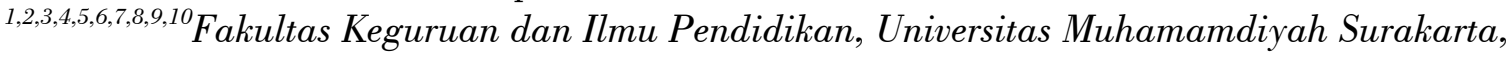 \\ Indonesia \\ ${ }^{11}$ Fakultas Keguruan dan Ilmu Pendidikan, STKIP Muhammdiyah Blora, Indonesia
}

\section{INFORMASI ARTIKEL}

\section{Histori Artikel:}

Submit: 12 Agustus 2020

Revisi: 26 Agustus 2020

Diterima: 31 Agustus 2020

Publikasi: 3 September 2020

Periode Terbit: Desember 2020

\section{Kata Kunci:}

berkarakter,

cerdas,

kreatif

\section{Correspondent Author:}

Ahmad Muhibbin

Fakultas Keguruan dan Ilmu Pendidikan

Universitas Muhammadiyah Surakarta,

Indonesia

Email: achmad.muhibbin@ums.ac.id

\begin{abstract}
ABSTRAK
Sumber Daya Manusia (SDM) yang berkualitas sangat dibutuhkan dalam mempersiapkan Generasi Emas 2045. Di mana Generasi Emas 2045 merupakan generasi yang ditunggu bangsa Indonesia. SDM berkualitas dapat diwujudkan melalui dunia pendidikan untuk berupaya mewujudkan generasi cerdas, kreatif, dan berkarakter. Cerdas dan kreati saja tidaklah cukup untuk mewujudkan generasi emas yang berkualitas, diperlukan juga adanya pendidikan karakter. Oleh karena itu, dalam kegiatan KKN-Dik mengacu pada pengupayaan generasi cerdas, kreatif, dan berkarakter melalui program kerja kami. Diharapkan dengan adanya program kerja KKN-Dik dapat membantu sekolah dalam inovasi pembelajaran untuk mempersiapkan Generasi Emas 2045 yang lebih baik.
\end{abstract}

\section{Pendahuluan}

Sumber Daya Manusia (SDM) yang berkualitas sangat menentukan kualitas dari sebuah kehidupan, termasuk kehidupan berbangsa. Kualitas SDM beruhungan dengan kualitas generasi yang ada. Kualitas dari generasi tentunya begantung dari kualitas pendidikan. Oleh karenanya, dalam mempersiapkan Generasi Emas Indonesia Tahun 2045 perlu dilakukan peningkatan kualitas SDM. Peningkatan tersebut dengan berupaya menyiapkan generasi cerdas, kreatif, dan berkarakter.

Generasi cerdas, kreatif, dan berkarakter diperlukan dalam rangka mempersiapkan generasi emas Indonesia tahun 2045 mendatang. Terbentuknya generasi cerdas, kreatif dan berkarakter dimulai dari dunia pendidikan. Keberhasilan dunia pendidikan dalam mengupayakan generasi cerdas, kreatif, dan berkarakter akan memberikan dampak besar pada tujuan pembangunan nasional secara keseluruhan.

Sebuah generasi yang cerdas dapat membantu dalam memajukan sebuah bangsa dan negara. Cerdas menurut Garner (dalam Rianto, 2015: 46) merupakan sebuah kemampuan untuk memecahkan masalah, menciptakan masalah yang kemudian dipecahkan, serta menciptakan dan menawarkan suatu pelayanan berharga dalam kebudayaan masyarakat. Selain definisi tersebut, Prayitno (2010) menjelaskan bahwa cerdas memiliki hubungan dengan kemampuan dalam memanipulasi serta mengolaborasikan unsur-unsur kondisi yang sedang dihadapi untuk sukses mencapai tujuan. 
e-ISSN 2716-0327

doi: 10.23917/bkkndik.v2i2.10487

Selain cerdas, kreatif juga diperlukan dalam pembentukan sebuah generasi. Kreatif yang pada penerapannya biasa disebut kreativitas menurut Budiarti (2015: 66) diartikan sebagai sebuah usaha produkti yang dihasilkan oleh seseorang. Kreativitas ini sangat diperlukan di dunia pendidikan terutama dalam hal mempelajari dan memahami materi. Kreativitas erat hubungannya dengan aktivitas sehari-hari yang dilakukan secara individu ataupun secara berkelompok, sehingga dengan mengembangkan kreativitas dalam dunia pendidikan peserta didik dapat memecahkan masalah yang dihadapinya.

Kreativitas menjadi salah satu komponen utama dari keterampilan-keterampilan dasar yang harus dimiliki pada abad ke-21. Dalam Partnership for 21st Century Skills (P21), kreativitas didefinisikan sebagai kemampuan untuk menawarkan gagasan-gagasan baru dan keterbukaan terhadap perspektif berbeda. Kreativitas dimulai dari kemampuan untuk berpikir kreatif, bekerja sama dengan orang lain secara kreatif, dan mengimplementasikan inovasi-inovasi (Battelle for Kids, 2019).

Generasi cerdas dan kreatif saja tidak cukup untuk membentuk generasi emas Indonesia. Selain cerdas dan kreatif, perlu didukung adanya pembentukan karakter yang positif. Pembangunan karakter (Character building) harus didahulukan dalam membangun sebuah bangsa. Menurut Soedarsono (2009: 46) dijelaskan bahwa, bangsa yang besar, maju, serta bermartabat dapat diperoleh dengan pembentukan karakter. Sedangkan Manullang (2009: 3) menjelaskan bahwa, pendidikan yang mendasar merupakan pendidikan karakter, karena karakter mewarnai sebuah perilaku.

Pendidikan karakter sebagaimana termuat dalam Grand Design Pembangunan Karakter 2010 (Budimansyah, 2010) menempatkan keluarga sebagai wadah yang sentral dalam pembangunan karakter peserta didik. Upaya pengembangan karakter dilakukan lewat proses penguatan dari orang tua/wali peserta didik terhadap perilaku berkarakter mulia yang dikembangkan di satuan pendidikan sekolah menjadi kegiatan keseharian di rumah. Prinsip pengembangan karakter kepada anak dengan menerapkan pola intervensi dan habituasi di setiap aktivitas mereka di rumah.

Pemerintah mempromosikan gerakan Penguatan Pendidikan Karakter (PPK) yang dikenalkan sejak tahun 2016. Munculnya Gerakan PPK tidak dapat dipisahkan dari dominasi aspek pengetahuan dibandingkan dengan pembangunan karakter di setiap jenjang penddikan (Kemendikbud, 2017). Karakter pada dasarnya adalah inti dari pendidikan, yaitu perubahan perilaku peserta didik untuk menjadi warga masyarakat dewasa dengan kematangan pikir, hati, dan rasa.

Effendy (2017) menjelaskan bahwa terdapat lima nilai utama pada prioritas PPK yang terintegrasi menjadi satu dan tidak dapat dipisahkan antara satu dengan yang lain yaitu, religius, nasionalis, mandiri, integritas, dan gotong royong. Nilai-nilai tersebut dijabarkan sebagai berikut:

Tabel 1. Nilai-nilai Utama Pendidikan Karakter

Nilai Perilaku dalam Kehidupan

Karakter

Religius Toleransi, cinta damai, persahabatan, berpendirian teguh, ketulusan, percaya diri, anti kekerasan, cinta lingkungan, tidak memaksakan kehendak, kerja sama antar pemeluk agama, mengharai perbedaan agama, melindungi yang kecil dan tersisih.

Nasionalis Taat peraturan/hukum, disiplin, cinta tanah air, menghormati keanekaragaman budaya, menjaga kekayaan budaya yang ada, rela berkorban, unggul dan berprestasi, menjaga lingkungan.

Mandiri Kerja keras, pantang menyerah/tangguh, kreati, proesional, berani, menjadi pembelajar sepanjang masa.

Integritas Jujur, adil, keteladanan, setia, cinta kebenaran, komitmen moral, antikorupsi, tanggungjawab, menghargai orang lain.

Gotong Kerja sama, menghargai, inklusi, Royong solidaritas, komitmen, empati, tolong menolong, musyawarah, antidiskriminasi, antikekerasan, sikap relawan.

Oleh karena itu, dalam rangka mengupayakan generasi cerdas, kreatif, dan berkarakter program kerja KKN-Dik kami terarah pada proses pendidikan di sekolah, khususnya di MIM Janti. Tujuan dari penelitian yang dilakukan adalah untuk mendeskripsikan program kerja KKN-Dik yang megarah kepada generasi cerdas, kreatif, dan berkarakter di MIM Janti.

\section{Metode Pelaksanaan}

Metode yang digunakan dalam penelitian ini adalah metode kualitatif dengan desain deskriptif analitis. 
Menurut Rosita (2013: 268) penelitian deskrifitf adalah sebuah penelitian menggunakan hasil yang valid berupa data yang dihasilkan dari instansi di mana penulis melakukan kegiatan penelitian, kemudian dalam desain penelitian analistis, peneliti melakukan peninjauan kembali (review) dari data yang telah diperoleh dengan memilah data yang berhubungan dengan penelitian penulis. Penelitian dilakukan pada waktu kegiatan KKNDik yang berlangsung dari bulan Januari sampai bulan Maret 2020 dan bertempat di MIM Janti.

\section{Hasil Pelaksanaan dan Pembahasan}

Program kerja dari kegiatan KKN-Dik yang dilakukan penulis mengarah pada pembentukan generasi cerdas, kreatif, dan berkarakter. Program kerja yang dilaksanakan bertujuan untuk memberikan sebuah pendidikan yang sebelumnya belum dilakukan di tempat kegiatan KKN-Dik. Program kerja yang dilakukan diantaranya:

\section{Sosialisasi Hidup Bersih dan Sehat serta Kegiatan Cuci Tangan Bersama}

Program kerja ini merupakan program yang dilaksanakan pertama. Program ini dilaksanakan tanggal 30 Januari 2020. Kegiatan ini mengarahkan peserta didik supaya melaksanakan pola hidup bersih dan sehat serta membiasakan diri untuk selalu mencuci tangan baik sebelum atau sesudah makan terutamanya. Tujuan dilaksanakannya program ini supaya peserta didik dapat mengerti pentingnya melakukan pola hidup bersih dan sehat. Selain itu, nilai yang dapat diambil dari kegiatan ini adalah kemandirian dan tanggungjawab siswa dalam melakukan pola hidup bersih dan sehat. Kemandirian serta tanggungjawab merupakan poin dalam pendidikan karakter.

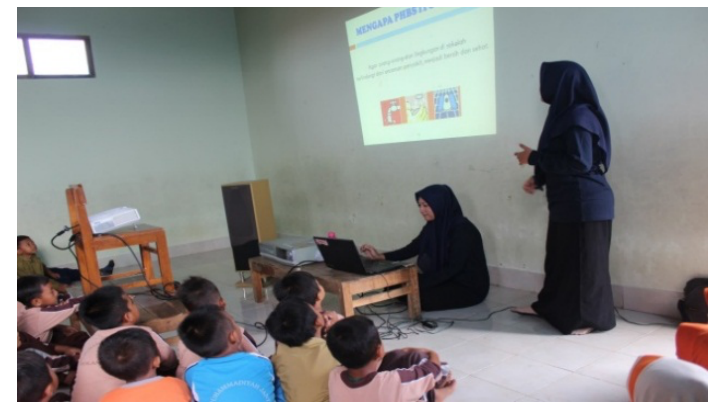

Gambar 1. Sosialisasi Hidup Bersih dan Sehat

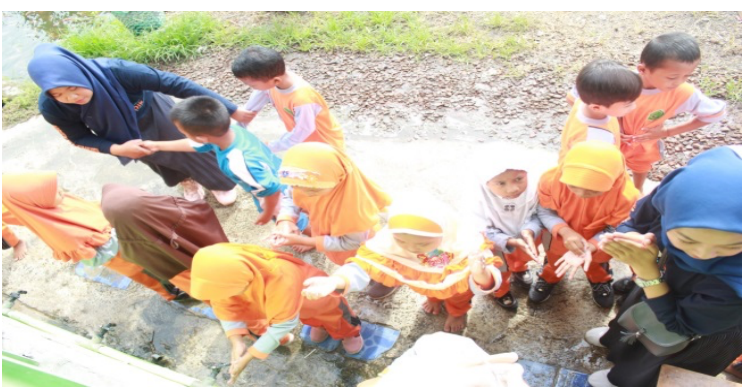

Gambar 2. Cuci Tangan Bersama

\section{Pengolahan Sampah Sederhana dan Penghijauan}

Program kerja yang dilaksanakan berikutnya merupakan pengolahan sampah sederhana dan penghijauan. Program ini dilaksanakan dalam dua tahap, yaitu pada tanggal 6 dan 7 Februari 2020. Kegiatan tahap pertama, yaitu program pengolahan sampah sederhana yang dilaksanakan pada tanggal 6 Februarin 2010. Tahap ini bertujuan untuk memanfaatkan botol bekas pakai untuk dijadikan pot. Kegiatan pengolahan sampah sederhana yang dilakukan bertujuan menanamkan sikap kreatif, kerja keras, peduli lingkungan, cinta damai, komunikatif yang merupakan sebagian besar dari poin pendidikan karakter yang ditekankan oleh kementrian pendidikan dan kebudayaan Indonesia.

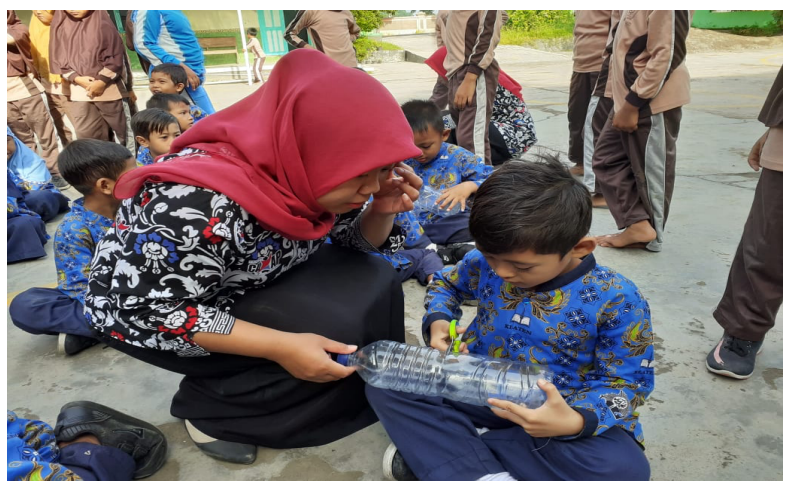

Gambar 3. Pengolahan Sampah Sederhana

Kegiatan tahap kedua, yaitu penghijauan yang dilaksanakan pada tanggal 7 Februari 2020 dengan tujuan menanamkan kepada peserta didik tentang pentingnya menjaga lingkungan dengan merawat tanaman dan belajar menanam tumbuhan. Kegiatan ini memiliki nilai pendidikan karakter yang berupa kerja keras, mandiri, peduli lingkungan, dan bersahabat. 


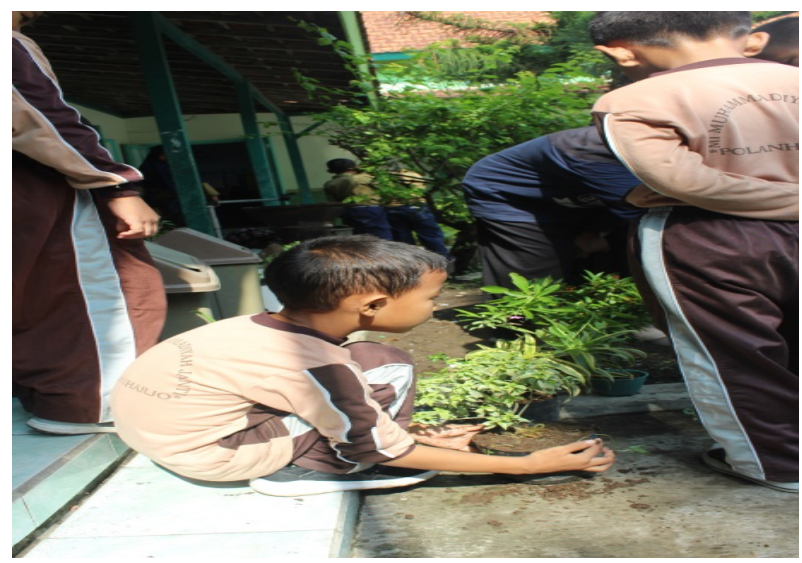

Gambar 4. Penghijauan

\section{Study Club}

Kegiatan berikutnya yang dilaksanakan merupakan kegiatan rutin yang hampir dilaksanakan setiap hari di posko KKN-Dik. Selain di posko, kegiatan study club juga dilaksanakan di sekolah pada hari Sabtu khusus kelas 6 untuk persiapan ujian nasional nantinya. Kegiatan study club ini dibentuk untuk menanamkan jiwa komunikatif dan untuk meningkatkan sikap demokratis dari peserta didik.

Peserta didik diajak untuk berdiskusi dan menyampaikan apa kesulitan yang dihadapi yang kemudian mereka diarahkan untuk memecahkan masalahnya itu dengan dibantu mahasiswa KKN. Poin dari kegiatan study club ini yang utama adalah mewujudkan sebuah generasi cerdas, dan juga ada nilai karakter yang dibentuk yang berupa sikap mandiri, toleransi, demokrasi, rasa keingin tahuan, dan juga sikap komunikatif.

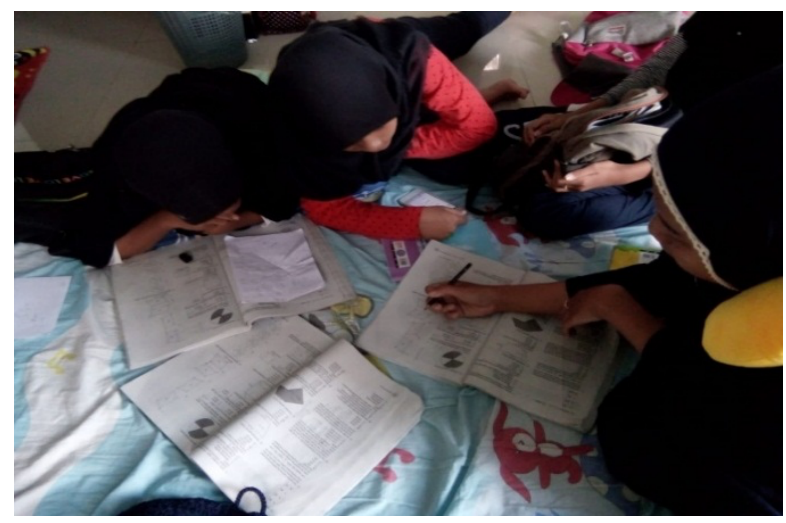

Gambar 5. Study Club

\section{Literasi Digital}

Program kerja digital literasi merupakan program kerja yang diperuntukkan bagi guru yang ada di MIM
Janti. Kegiatan digital literasi dilaksanakan kondisional sesuai dengan longgarnya jadwal mengajar guru atau dengan kata lain di jeda waktu mengajar guru. Kegiatan ini bertujuan memberikan pelatihan sederana dalam menggunakan media digital seperti laptop untuk kegiatan pembelajaran.

Kegiatan ini dilakukan karena digitalisasi telah merambah diberbagai sisi kehidupan tidak terkecuali pendidikan. Guru di era sekarang ini juga dituntut harus menguasai dan mempelajari perkembangan teknologi dan dapat menerapkannya dalam proses pembelajaran. Selain hal itu, menariknya sebuah pembelajaran juga akan mendukung tercapainya tujuan pembelajaran. Menariknya pembelajaran tersebut salah satunya dapat dilakukan dengan memanfaatkan media yang ada.

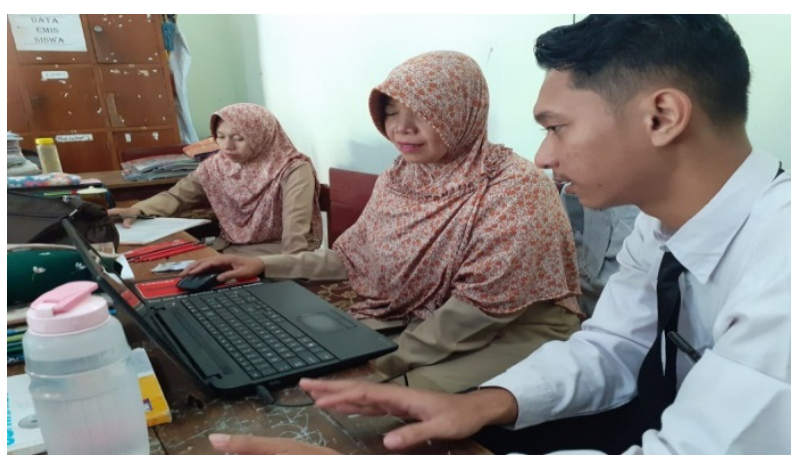

Gambar 6. Digital Literasi

\section{Pengembangan Budaya Literasi melalui Pojok Baca}

Membaca merupakan sebuah kegiatan rutin yang dilakukan oleh setiap orang, terutama pelajar. Dalam rangka meningkatkan minat baca dan juga memberikan ruang untuk peserta didik, kami membuat program kerja pojok baca. Pojok baca sendiri berfungsi sebagai tempat untuk membaca yang berada di pojok kelas. Peserta didik dapat memanfaatkan untuk mengisi waktu luang ketika istirahat dan jam tertentu untuk meningkatkan pengetahuannya dengan membaca. Peserta didik juga lebih nyaman dalam melakukan kegiatan memperoleh informasi melalui membaca.

Program kerja pojok baca mengandung nilai pendidikan karakter yang menjadi pusat tujuan pengadaan pojok baca tersebut. Nilai utama yang terkandung adalah gemar membaca, rasa ingin tahu, dan juga mandiri. 


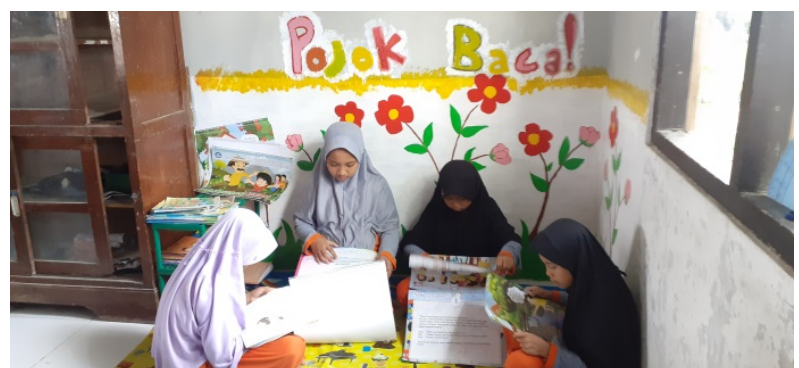

Gambar 7. Pojok Baca

\section{Pengajian Akbar dan Bakti Sosial}

Program kerja yang mengarah ke masyarakat, yaitu diadakannya pengajan akbar yang dilaksanakan pada Minggu pagi tanggal 16 Februari 2020 pukul 19.30 WIB di Masjid Al-Huda, Dukuh Cabean yang berdekatan dengan MIM Janti. Kegiatan tersebut yang mengusung tema "Menebar Samara Menuai Surga" ini diisi oleh Dr. Hanifullah Syukri, M.Hum dan dihadiri oleh warga setempat dan juga beberapa siswa yang bertempat tinggal di dekat lokasi.

Program kerja pengajian sendiri dapat befungsi sebagai sarana meningkatkan religiusitas warga setempat. Selain pengajian akbar terdapat kegiatan lain yang dilaksanakan pada Minggu sore, meliputi kegiatan bakti sosial berupa cek kesehatan gratis dan pembagian sembako kepada warga sekitar yang kurang mampu. Melalui kegiatan tersebut diharapkan dapat meningkatkan nilai sosial seperti, gotong royong, peduli sesama, dan juga menanamkan sikap empati.

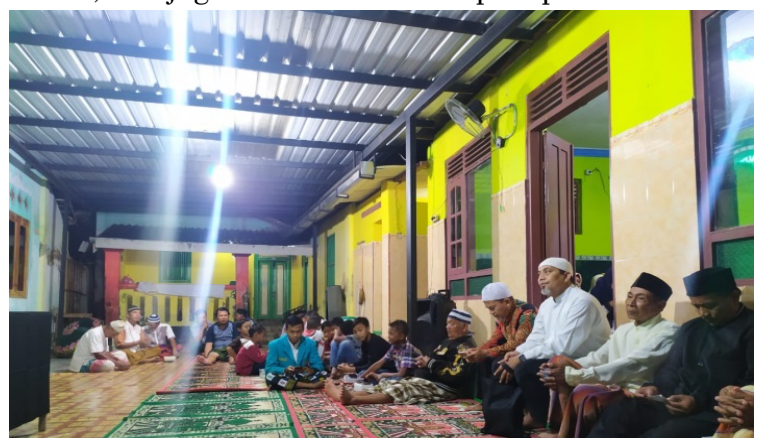

Gambar 8. Pengajian Akbar

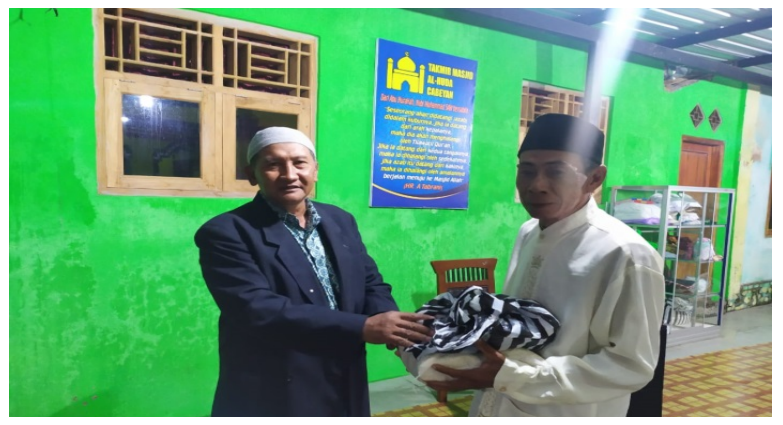

Gambar 9. Bakti Sosial

\section{English Camp}

Program kerja English Camp merupakan kegiatan menginap dengan basis bahasa Inggris yang dilaksanakan pada tanggal 28 Februari 2020 sore sampai tanggal 29 Februari 2020 siang. Kegiatan ini dikhsuskan untuk siswa kelas V dan kelas VI di MIM Janti. Pelaksanaan kegiatan English Camp sendiri berupa pemberian materi, praktik, serta game tentang penggunaan bahasa Inggris di kehidupan sehari-hari.

Kegiatan English Camp sendiri bertujuan supaya siswa lebih berani berbicara menggunakan bahasa Inggris. Selain itu, dengan kegiatan English Camp ini, peserta didik diharapkan akan lebih berani mengekspresikan diri dalam berbicara menggunakan bahasa Inggris di depan umum. Adapun nilai pendidikan karakter yang diajarkan melalui program kerja English Camp diantaranya adalah sikap mandiri, bersahabat, komunikati, rasa ingin tahu, disiplin, kerja keras, menghargai prestasi, religius, demokratis, peduli, dan juga berani.

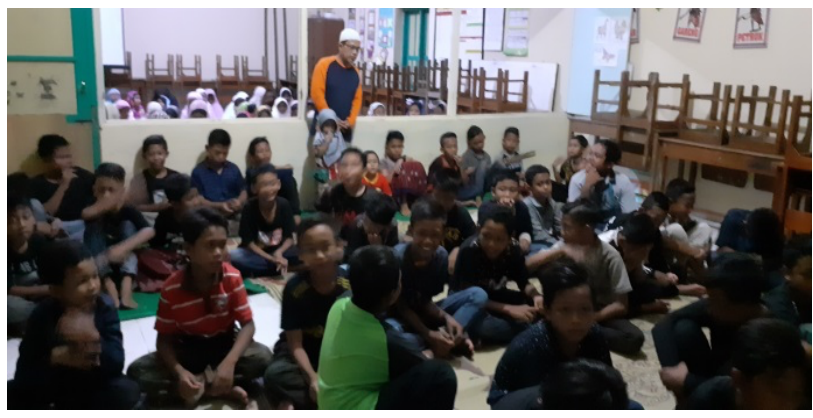

Gambar 10. English Camp

\section{Simpulan}

Generasi Emas Indonesia Tahun 2045 merupakan generasi yang ditunggu bangsa ini. Generasi yang merupakan cita-cita untuk mencapai kemajuan bangsa yang luar biasa. Dalam mewujudkan cita-cita tersebut 
perlu adanya pembentukan generasi yang kompeten. Cerdas dan kreatif saja tidak cukup dalam pembangunan sebuah bangsa diperlukan adanya karakter.

Pendidikan karakter merupakan pendidikan yang sangat utama dan mendasar dalam membangun sebuah bangsa. Melalui keberhasilan dunia pendidikan dalam mengupayakan generasi cerdas, kreatif, dan berkarakter akan mendukung juga keberhasilan tujuan pembangunan nasional. Oleh karena itu, dalam dunia pendidikan harus mengutamakan kegiatan yang positif dan bermanfaat untuk mempersiapkan Generasi Emas Indonesia Tahun 2045, dan menjadi acuan kami dalam membentuk dan melaksanakan program kerja KKN-Dik di MIM Janti.

\section{Daftar Pustaka}

Battelle for Kids. (2019). Frameworks \& Resources. http://www.battelleforkids.org/networks/p2l/framew orks-resources

Budiarti, Yesi. 2015. Pengembangan Kemampuan Kreativitas dalam Pembelajaran IPS. Jurnal Pendidikan Ekonomi UM Metro, Vol. 3, No. 1. Hal. 61-72 (ISSN: 2242-9949)

Budimansyah, D. (2010). Penguatan Pendidikan Kewarganegaraan Untuk Membangun Karakter Bangsa. Widya Aksara Press.

Effendy, Muhadjir. 2017. Penguatan Pendidikan Karakter jadi Pintu Masuk Pembenahan Pendidikan Nasional. (diakses online melalui: https://www.kemendikbud.go.id/ main/blog/2017/07/penguatan-pendidikan- karakter-jadi-pintu-masuk-pembenahanpendidikan-nasional diakses pada: 5 Maret 2020 pukul 18.25)

Kemendikbud. (2017). Penguatan Pendidikan Karakter Jadi Pintu Masuk Pembenahan Pendidikan Nasional [Strengthening Character Education Becomes an Entry Point for Improving National Education]. https://www.kemdikbud.go.id/main/blog/2017/07/p enguatan-pendidikan-karakter-jadi-pintu-masukpembenahan-pendidikan-nasional

Manullang, Belferik. 2013. Grand Desain Pendidikan Karakter Generasi Emas 2045. Jurnal Pendidikan Karakter, No. 1. Hal. 1-14.

Prayitno. 2010. Potensi Pembelajaran Kooperatif dalam Memberdayakan Prestasi Belajar Siswa. (diakses online melalui: http://baskorol.blogspot.com pada 3 Maret 2020 pukul 19.30)

Rianto, Hadi. 2015. Peran Pendidikan Pancasila dan Kewarganegaraan Membangun Generasi Cerdas Berkarakter. Jurnal Pendidikan sosial, Vol. 2, No. 1. Hal. 14-21.

Rosita, Lita Rara. (2018). Perancangan Sistem Laporan Akuntansi Laporan Keuangan Standar PSAK 45-s. Accounting Information System and Information Technology Business Enterprise. Vol 03, No.01. Hal. 262-274 (P-ISSN: 2252-9853 diakses online melalui https://search.unikom.ac.id/ index.php/aisthebest/article/ view/1817/1209 pada 3 Maret 2020 Pukul 19.20).

Soedarsono, Soemarmo. 2009. Karakter Mengantar Bangsa dari Gelap Menuju Terang. Jakarta: Elex Media Komputindo, Kompas Gramedia. 